\title{
LANDASAN KONSTITUSIONAL PEMBENTUKAN PERATURAN PERUNDANG-UNDANGAN
}

\author{
Oleh : Evi Noviawati, S.H., M.H.")
}

\begin{abstract}
Establishment of good legislation should meet the constitutional formal foundations and constitutional material foundations. Formal constitutional foundation is intended to provide procedural legitimacy to the formation of laws and regulations, while the constitutional material basis is intended to give a sign that the legislation that is formed is the elaboration of the articles of the 1945 Constitution of the State of the Republic of Indonesia.
\end{abstract}

Keywords: Constitutional formal basis, constitutional material foundation.

\begin{abstract}
Abstrak
Pembentukan peraturan perundang-undangan yang baik harus memenuhi landasan formal konstitusional dan landasan materiil konstitusional. Landasan formal konstitusional dimaksudkan untuk memberikan legitimasi prosedural terhadap pembentukan peraturan perundang-undangan, sedangkan landasan materiil konstitusional dimaksudkan untuk memberikan tanda bahwa peraturan perundangundangan yang dibentuk merupakan penjabaran dari pasal-pasal Undang-Undang Dasar Negara Republik Indonesia Tahun 1945.

Kata Kunci : Landasan formal konstitusional, landasan materiil konstitusional.
\end{abstract}

\section{Pendahuluan}

Pengertian peraturan perundang-undangan menurut Pasal 1 angka 2 Undang-Undang Nomor 12 Tahun 2011 tentang Pembentukan Peraturan Perundang-undangan adalah peraturan tertulis yang memuat norma hukum yang mengikat secara umum dan dibentuk atau ditetapkan oleh lembaga negara atau pejabat yang berwenang melalui prosedur yang ditetapkan dalam Peraturan Perundang-undangan.

Sedangkan Van Der Tak mendefinisikan Peraturan Perundang-undangan sebagai kaidah hukum tertulis yang dibuat oleh pejabat yang berwenang, berisi aturan-aturan tingkah laku yang bersifat abstrak dan mengikat umum.

\footnotetext{
* Dosen Tetap Fakultas Hukum Universitas Galuh
} 
Menurut A. Hamid Attamimi bahwa dalam konteks pembentukan Hukum Nasional, terdapat 3 (tiga) fungsi utama IImu Perundang-undangan, yaitu :

1. Untuk memenuhi kebutuhan hukum dalam kehidupan bermasyarakat, berbangsa dan bernegara yang senantiasa berkembang;

2. Untuk menjebatani lingkup hukum adat dengan hukum yang tidak tertulis lainnya; atau

3. Untuk memenuhi kebutuhan kepastian hukum tidak tertulis bagi masyarakat.

Ada 3 landasan yang harus dipenuhi dalam pembentukan perundangundangan, yaitu :

1. Landasan Filosofis :

Yaitu dasar filsafat, pandangan atau ide yang menjadi dasar cita hukum sewaktu menuangkan keinginan ke dalam suatu rancangan peraturan perundang-undangan. Ide yang menjadi dasar cita hukum tersebut merupakan sistim nilai yang tumbuh dalam masyarakat mengenai hal-hal yang baik dan buruk sebagai pedoman dan tutunan berperilaku dalam kehidupannya. Di Indonesia yang menjadi landasan filosofis pembentukan peraturan perundangundangan adalah Pancasila.

2. Landasan Politis/Sosiologis

Landasan Politis adalah Garis kebijaksanaan politik yang menjadi dasar selanjutnya bagi pembentukan peraturan peraturan perundang-undangan.

Landasan sosiologis adalah landasan yang mencerminkan kenyataan yang hidup dalam masyarakat, kenyataan itu dapat berupa kebutuhan atau tuntutan atau masalah-masalah yang dihadapi oleh masyarakat. Landasan sosiologis ini diharapkan peraturan perundang-undangan yang di buat akan diterima oleh masyarakat secara wajar, bahkan spontan.

3. Landasan Yuridis

Bahwa setiap peraturan perundang-undangan maka harus merujuk pada peraturan yang lebih tinggi secara hierarki agar tidak bertentangan antar satu dengan yang lainnya sebagai satu sistem kesatuan.

Landasan yuridis dibedakan menjadi 2 yaitu :

\section{a. Landasan Yuridis Formal :}

Landasan yuridis yang memberi kewenangan bagi instansi tertentu untuk membuat peraturan perundang-undangan; 


\section{b. Landasan Yuridis Materil :}

Landasan yuridis dari segi isi suatu peraturan hukum untuk diatur lebih lanjut ke dalam peraturan perundang-undangan tertentu.

\section{Pembahasan}

Dalam pembentukan peraturan perundang-undangan ada beberapa aspek yang harus ditempuh, yaitu aspek formil dan aspek materiil. Yang dimaksud aspek formil atau aspek prosedural menyangkut landasan formal konstitusional pembentukan peraturan perundang-undangan. Sedangkan aspek materiil menyangkut materi muatan yang harus diatur dalam peraturan perundangundangan sesuai dengan jenis dan tingkatannya (hierarki sesuai dengan apa yang diperintahkan baik secara tegas maupun secara tersirat dalam Undang-Undang Dasar Negara Republik Indonesia Tahun 1945 dan / atau berdasarkan asas konstitusionalisme serta asas negara hukum (rule of law) yang terdiri atas supremasi, ekualiti, hukum dasar bersumber pada Hak Azasi Manusia atau negara berdasar hukum (rechtstaat) yang terdiri atas pengakuan Hak Azasi Manusia, pemisahan kekuasaan, wetmatige bestuur, dan peradilan Tata Usaha Negara.

Untuk memberikan legitimasi prosedural terhadap pembentukan peraturan perundang-undangan, terdapat pasal-pasal yang menjadi landasan konstitusional yaitu :

1. Undang-Undang Dasar Negara Republik Indonesia Tahun 1945 adalah Pasal 3 jo Pasal 37 UUD Negara RI Tahun 1945;

2. Undang-Undang adalah Pasal 5 ayat (1), Pasal 20, Pasal 21, dan Pasal 22 Undang-Undang Dasar Negara Republik Indonesia Tahun 1945;

3. Peraturan Pemerintah Pengganti Undang-Undang (Perpu) landasan formal konstitusionalnya adalah Pasal 22 Undang-Undang Dasar Negara Republik Indonesia Tahun 1945;

4. Peraturan Pemerintah, landasan formal konstitusionalnya adalah Pasal 5 ayat (2) Undang-Undang Dasar Negara Republik Indonesia Tahun 1945;

5. Peraturan Presiden, landasan formal konstitusionalnya adalah Pasal 4 ayat (1) Undang-Undang Dasar Negara Republik Indonesia Tahun 1945;

6. Peraturan Daerah, landasan formalnya adalah Pasal 18 Undang-Undang Dasar Negara Republik Indonesia Tahun 1945, khsusnya Pasal 18 ayat 
(6) Undang-Undang Dasar Negara Republik Indonesia Tahun 1945;

Pasal-pasal tersebut di atas secara teknis dapat dicantumkan pada dasar hukum "mengingat" Peraturan Perundang-undangan, sesuai dengan jenis Peraturan Perundang-undangan yang dibentuk tersebut. Apabila pencantumannya salah maka kemungkinan akan dijadikan dasar dalam pengujian secara formil di Mahkamah Konstitusi apabila pengujiannya terhadap Undang-Undang Dasar Negara Republik Indonesia Tahun 1945, dan di Mahkamah Agung apabila berbentuk peraturan perundang-undangan di bawah Undang-Undang/Peraturan Pemerintah Pengganti Undang-Undang.

Sedangkan landasan materiil konstitusional diperlukan untuk memberikan tanda bahwa peraturan perundang-undangan yang dibentuk merupakan penjabaran dari pasal-pasal Undang-Undang Dasar Negara Republik Indonesia Tahun 1945 yang juga dicantumkan dalam dasar hukum "mengingat" suatu peraturan perundang-undangan yang dibentuk, ada yang disebut dengan. Pencantuman pasal-pasal Undang-Undang Dasar Negara Republik Indonesia Tahun 1945 tersebut disesuaikan dengan materi muatan yang akan dijabarkan dalam batang tubuh peraturan perundang-undangan tersebut. Misalnya akan dibentuk Rancangan Undang-Undang (RUU) tentang Partai Politik, maka landasan materiil konstitusionalnya adalah Pasal 28 Undang-Undang Dasar Negara Republik Indonesia Tahun 1945, karena pasal ini memuat hak-hak dasar manusia (dalam hal ini warga negara) untuk menyatakan ekspresinya dalam suatu kegiatan politik atau membentuk organisasi partai politik. Pencantuman Pasal 33 Undang-Undang Dasar Negara Republik Indonesia Tahun dalam dasar hukum "mengingat" suatu Rancangan Undang-Undang memberikan indikasi bahwa landasan materiil konstitusional Rancanga Undang-Undang adalah yang berkaitan dengan kesejahteraan atau kegiatan di bidang ekonomi dan kekayaan alam (SDA) yang dijabarkan lebih lanjut dalam batang tubuh Rancangan Undang-Undang /Undang-Undang tersebut.

Substansi suatu Rancangan Undang-Undang/ Undang-Undang yang dijabarkan sejak konsiderans "menimbang", penjabaran dalam batang tubuh sampai dengan penjelasan Rancangan Undang-Undang/ Undang-Undang tidak boleh bertentangan dengan landasan materiil konstitusional, artinya apabila kita mencantumkan Pasal 33 Undang-Undang Dasar Negara Republik Indonesia 
Tahun 1945 sebagai landasan materiil konstitusional suatu Rancangan UndangUndang/ Undang-Undang, maka penjabarannya dalam "menimbang", batang tubuh, sampai dengan penjelasan Rancangan Undang-Undang / Undang-Undang tersebut tidak boleh bertentangan dengan esensi dari Pasal 33 Undang-Undang Dasar Negara Republik Indonesia Tahun 1945. Secara mutatis mutadis uraian di atas berlaku juga untuk pembentukan suatu peraturan daerah.

Untuk menghasilkan suatu peraturan perundang-undangan yang baik diperlukan teknik perancangan pembentukan peraturan perundang-undangan, yaitu :

\section{Tujuan pembentukan}

Tujuan pembentukan harus jelas atau produk Undang-Undang tersebut ada sasarannya yang akan dicapai/dapat mengatur masyarakat yang tidak beraturan menjadi masyarakat yang beraturan.

\section{Fungsi pembentukan}

Bentuk suatu peraturan peraturan perundang-undangan agar memenuhi fungsinya sebagai sumber pengenal (kenvorm), dibagi atas 4 bagian besar yaitu :

a. penamaan;

b. pembukaan;

c. batang tubuh, yang terdiri dari: 1) ketentuan umum; 2) ketentuan materi; 3) ketentuan pidana; 4) ketentuan peralihan; 5) ketentuan penutup

d. penutup.

\section{Mengetahui, menguasai materi yang diatur :}

\section{a. menguasai :}

Materi harus dikuasai benar oleh pembuat undang-undang sehingga menghasilkan produk Undang-Undang yang benar dan dapat mencapai tujuan atau sasaran yang diinginkan

b. mengetahui :

Maksud pengetahuan pengetahuan tersebut meliputi :

1) Apakah materi tersebut pernah diatur sebelumnya atau tidak;

2) Tujuan dari materi yang diatur;

3) Bentuk peraturan perundang-undangan mana yang tepat untuk mengaturnya;

4) Pandangan jauh kedepan. 
Bagirmanan memberikan pandangan bagaimana teknik perancangan peruaturan perundang-undangan yang baik, yaitu :

1. Perumusan tersusun secara sistematis, sederhana dan baku;

2. Sebagai kaidah mampu mencapai daya guna dan hasil guna yang maksimal baik dalam wujud ketertiban maupun keadilan;

3. Sebagai gejala sosial merupakan perwujudan pandangan hidup kesadaran hukum dan rasa keadilan masyarakat;

4. Sebagai sistim hukum harus mencerminkan suatu rangkaian sistim yang teratur dari keseluruhan sistim hukum yang ada

\section{Konsiderans "Menimbang"}

Dalam lampiran Undang-Undang Republik Indonesia Nomor 12 Tahun 2011 tentang Pembentukan Peraturan Perundang-undangan butir 18 dinyatakan bahwa : "Konsiderans memuat uraian singkat mengenai pokok pikiran yang menjadi pertimbangan dan alasan pembentukan Peraturan Perundang-undangan". Sedangkan di dalam butir 19 dinyatakan bahwa : "Pokok pikiran pada konsiderans Undang-Undang, Peraturan Daerah Provinsi, atau Peraturan Daerah Kabupaten/Kota memuat unsur filosofis, sosiologis, dan yuridis yang menjadi pertimbangan dan alasan pembentukannya yang penulisannya ditempatkan secara berurutan dari filosofis, sosiologis, dan yuridis".

Rumusan pada butir 18 dan 19 yang dimuat dalam Lampiran UndangUndang Pembentukan Peraturan Perundangundangan harus mencerminkan landasan konstitusional baik secara formal maupun secara materiil yang kemudian dituangkan dalam konsideranns "menimbang". Unsur-unsur filosofis yang termuat dalam latar belakang pembuatan suatu undang-undang merupakan inti dari landasan formal dan materiil konstitusional. Unsur-unsur filosofis ini terkandung dalam Pembukaan Undang-Undang Dasar Negara Republik Indonesia Tahun 1945 dan tersurat maupun tersirat dalam aturan/norma dasar dalam pasal-pasal Undang-Undang Dasar Negara Republik Indonesia Tahun 1945 dan tersebar dalam kehidupan masyarakat yang secara prinsip telah "dirangkum" dan "dimuat" dalam nilai-nilai yang ada pada setiap sila dari Pancasila. 
Dalam pembukaan dan pasal-pasal Undang-Undang Dasar Negara Republik Indonesia Tahun 1945 termuat berbagai hak dasar manusia (HAM) yang harus diperhatikan secara sungguh-sungguh dalam setiap pembuatan peraturan perundang-undangan. Misalnya kita akan membuat suatu Rancangan Undang-Undang /Undang-Undang yang berkaitan dengan pemilihan umum, maka dalam "menimbang" harus diuraikan secara filosofis apa itu pemilihan umum dan bagaimana cara pemilihannnya, dalam suatu uraian kalimat yang singkat, padat, dan dikaitkan dengan asa demokrasi dari sila ke-4 Pancasila.

Merumuskan landasan filosofis dikaitkan dengan landasan materiil konstitusional tidaklah semudah mengatakannya. Dalam berbagai pengalaman, pembuatan undang-undang di Dewan Perwakilan Rakyat (DPR) selama Orde Baru, patokan secara runtut "menimbang" suatu undang-undang dimulai dengan Pancasila, kemudian Undang-Undang Dasar Negara Republik Indonesia Tahun 1945, dan nilai-nilai lain yang berlaku di masyarakat dikaitkan dengan substansi undang-undang yang dibentuk.

Latar belakang sosiologis dalam "menimbang' suatu undang-undang dirumuskan dalam kalimat yang isinya memberikan indikasi fakta-fakta yang terjadi dalam masyarakat. Apabila secara filosofis kaitannya adalah nila-nilai misalmya "kebenaran", "keburukan","keadilan", maka dalam latar belakang sosiologis yang dimuat dalam "menimbang" adalah fakta atau keadaaan nyata dalam masyarakat. Misalnya dalam Undang-Undang Nomor 7 Tahun 2017, latar belakang sosiologisnya adalah adanya ...

Latar belakang yuridis dalam "menimbang" suatu undang-undang dirumuskan dalam kalimat yang berkaitan dengan pelaksanaan suatu undangundang atau peraturan perundang-undangan baik yang menjadi dasar hukum "mengingat maupun yang berkaitan secara langsung dengan substansi Rancangan Undang-Undang/Undang-Undang tersebut.

Semua latar belakang filosofis, sosiologis maupun yuridis sebagaimana diuraikan di atas akan bermuara pada butir akhir dari suatu "menimbang' yang juga merupakan latar belakang yuridis pembentukan suatu peraturan perundang-undangan.

Contoh "menimbang" (dikutip dari Undang-Undang Republik Indonesia Nomor 7 Tahun 2017 tentang Pemilihan Umum) : 
a. bahwa untuk menjamin tercapainya cita-cita dan tujuan nasional sebagaimana termaktub dalam pembukaan Undang-Undang Dasar Negara Republik Indonesia Tahun 1945 perlu diselenggarakan pemilihan umum untuk memilih anggota Dewan Perwakilan Rakyat, anggota Dewan Perwakilan Daerah, Presiden dan Wakil Presiden, dan untuk memilih anggota Dewan perwakilan Rakyat Daerah, sebagai sarana perwujudan kedaulatan rakyrat untuk menghasilkan wakil rakyat dan pemerintahan negara yang demokratis berdasarkan pancasila dan Undang-Undang Dasar Negara Republik Indonesia Tahun 1945;

b. bahwa. diperlukan pengaturan pemilihan umum sebagai perwujudan sistem ketatanegaraan yang demokratis dan berintegritas demi menjamin konsistensi dan kepastian hukum serta pemilihan umum yang efektif dan efisien;

c. bahwa pemilihan umum wajib menjamin tersalurkannya suara rakyat secara langsung, umum, bebas, rahasia, jujur, dan adil;

d. bahwa Undang-Undang Nomor 42 Tahun 2008 tentang Pemilihan Umum Presiden dan Wakil presiden, Undang-Undang Nomor 15 Tahun 2011 tentang penyelenggaraan Pemilihan Umum, dan Undang-Undang Nomor 8 Tahun .2012 tentang Pemilihan Umum Anggota Dewan Perwakilan Rakyat, Dewan Perwakilan Daerah dan Dewan Perwakilan Rakyat Daerah perlu disatukan dan disederhanakan menjadi satu undang-undang sebagai landasan hukum bagi pemilihan umum secara serentak;

e. bahwa berdasarkan pertimbangan sebagaimana dimaksud dalam huruf $a$, huruf $b$, huruf $c$, dan huruf $d$, perlu membentuk UndangUndang tentang Pemilihan Umum.

Dari rumusan kalimat "menimbang" di atas, terlihat dengan nyata bahwa pada huruf a, jelas merupakan latar belakang filosofis tujuan penyelenggaraan pemilihan umum sesuai dengan amanat Undang-Undang Dasar Republik Indonesia 1945 beserta asas-asasnya, yaitu untuk memilih anggota Dewan Perwakilan Rakyat, anggota Dewan Perwakilan Daerah, Presiden dan Wakil Presiden, dan untuk memilih anggota Dewan perwakilan 
Rakyat Daerah sebagai sarana perwujudan kedaulatan rakyrat untuk menghasilkan wakil rakyat dan pemerintahan negara yang demokratis berdasarkan pancasila dan Undang-Undang Dasar Negara Republik Indonesia Tahun 1945.

Sedangkan pada huruf b mengandung latar belakang sosiologis yaitu untuk mewujudkan sistem ketatanegaraan yang demokratis dan berintegritas demi menjamin konsistensi dan kepastian hukum serta pemilihan umum yang efektif dan efisien.

Huruf c mengandung latar belakang yuridis ( Undang-Undang yang lama sudah tidak sesuai) yang bermuara pada aspek yuridis pula dengan perlunya membentuk Undang-Undang yang baru.

\section{Dasar Hukum "Mengingat"}

Dalam Lampiran Undang-Undang Nomor 12 Tahun 2011 tentang pembentukan peruaturan perundang-undangan butir 28 dinyatakan bahwa dasar hukum diawali dengan kata "mengingat" yang memuat dasar kewenangan pembentukan peraturan perundang-undangan dan peraturan perundang-undangan yang memerintahkan pembentukan peraturan perundang-undangan.

Ketentuan dalam butir 28 tersebut di atas berisi landasan formal dan materiil konstitusional, apabila menyangkut Undang-Undang Dasar Negara Republik Indonesia Tahun 1945. Sedangkan apabila menyangkut peraturan perundang-undangan lain di bawah Undang-Undang Dasar Negara Republik Indonesia Tahun 1945 dan Ketetapan MPR disebut landasan formal dan materiil yuridis (yuridis formal/materiil) pembentukan peraturan perundangundangan. Misalnya landasan formal dan materiil konstitusional pembentukan UU RI Nomor 7 Tahun 2017 tentang Pemilihan Umum sebagaimana dikutipkan dari aslinya adalah :

a. Pasal 1 ayat (2) Undang-Undang Dasar Negara Republik Indonesia Tahun 1945 (materiil);

b. Pasal 5 ayat (1) Undang-Undang Dasar Negara Republik Indonesia Tahun 1945 (formal);

c. Pasal 6 Undang-Undang Dasar Negara Republik Indonesia Tahun 1945 (materiil); 
d. Pasal 6A Undang-Undang Dasar Negara Republik Indonesia Tahun 1945 (materiil);

e. Pasal 18 ayat (3) Undang-Undang Dasar Negara Republik Indonesia Tahun 1945 (materiil);

f. Pasal 19 ayat (1) Undang-Undang Dasar Negara Republik Indonesia Tahun 1945 (materiil);

g. Pasal 20 Undang-Undang Dasar Negara Republik Indonesia Tahun 1945 (materiil);

h. Pasal 22C ayat (1) Undang-Undang Dasar Negara Republik Indonesia Tahun 1945 (materiil);

i. Pasal 22E Undang-Undang Dasar Negara Republik Indonesia Tahun 1945 (materiil);

Jadi ada 9 pasal dalam Undang-Undang Dasar Negara Republik Indonesia Tahun 1945 yang merupakan landasan formal dan materiil konstitusional pembentukan Undang-Undang Nomor 7 Tahun 2017 tentang pemilihan umum.

Sedangkan Landasan yuridis formal dan materiil atau yang merupakan sumber hukum (dalam bentuk Undang-Undang) dari pembentukan Undang-Undang Republik Indonesai Nomor 7 Tahun 2017 yang dicantumkan dalam dasar hukum "mengingat" memang tidak ada, akan tetapi dapat diambil contoh lain dari sumber hukum pembentukan Undang-Undang Republik Indonesia Nomor 10 Tahun 2016 Tentang Pemilihan Gubernur, Bupati, dan Walikota, bahwa dasar hukum "mengingat" adalah : UndangUndang Republik Indonesia Nomor 1 Tahun 2015 tentang Penetapan Peraturan Pemerintah Pengganti Undang-Undang Republik Indonesai Nomor 1 Tahun 2014 tentang Pemilihan Gubernur, Bupati, dan Walikota menjadi Undang-Undang. Undang-Undang tersebut merupakan sumber hukum pembentukan Undang-Undang Republik Indonesia Nomor Nomor 10 Tahun 2016 karena substansi yang dimuat dalam Undang-Undang Republik Indonesia Nomor 10 Tahun 2016 sangat erat kaitannya atau bersumber dari undang-undang tersebut. 


\section{Kesimpulan}

Berdasarkan uraian di atas dapat disimpulkan bahwa untuk membentuk peraturan perundang-undangan yang baik harus memenuhi landasan konstitusional, baik landasan formil konstitusional maupun landasan materiil konstitusional. Landasan formal konstitusional dimaksudkan untuk memberikan legitimasi procedural terhadap pembentukan peraturan perundang-undangan, sedangkan landasan materiil konstitusional dimaksudkan untuk memberikan tanda bahwa peraturan perundang-undangan yang dibentuk merupakan penjabaran dari pasal-pasal Undang-Undang Dasar Negara Republik Indonesia Tahun 1945 yang juga dicantumkan dalam dasar hokum "mengingat" suatu peraturan perundang-undangan yang akan dibentuk.

\section{DAFTAR PUSTAKA}

\section{Buku-buku :}

Maria Farida, 1996, Ilmu Perundang-undangan (Dasar-Dasar dan Pembentukannya, Bagian Pertama dari IImu Pengetahuan Perundang-undangan), Jakarta, Sekretaraiat Konsorsium IImu Hukum Universitas Indonesia.

HAS Natabaya, 2006, Sistem Peraturan Perundang-undangan Indonesia, Jakarta, Konpress.

\section{Peraturan Perundang-undangan :}

Undang-Undang Dasar Negara Republik Indonesia Tahun 1945

Undang-Undang Republik Indonesia Nomor 12 Tahun 2011 tentang Pembentukan Peraturan Perundang-undangan

Undang-Undang Republik Indonesia Nomor 10 Tahun 2016 Tentang Pemilihan Gubernur, Bupati, dan Walikota,

Nomor 7 Tahun 2017 tentang Pemilihan Umum 